\title{
Observations of trace gases and aerosols over the Indian Ocean during the monsoon transition period
}

\author{
T K Mandal ${ }^{1}$, Ateef Khan ${ }^{1}$, Y Nazeer Ahammed ${ }^{1}$, R S Tanwar ${ }^{1}$, R S Parmar ${ }^{1}$, \\ K S Zalpuri ${ }^{1}$, Prabhat K Gupta ${ }^{1}$, S L Jain ${ }^{1}$, Risal Singh ${ }^{1}$, A P Mitra ${ }^{1}$, S C Garg ${ }^{1}$, \\ A Suryanarayana ${ }^{2}$, V S N Murty ${ }^{2}$, M Dileep Kumar ${ }^{2}$ and Andrew J Shepherd ${ }^{3}$ \\ ${ }^{1}$ National Physical Laboratory, New Delhi 110 012, India. \\ ${ }^{2}$ National Institute of Oceanography, Dona Paula, Goa 403 004, India. \\ ${ }^{3}$ National Ocean and Atmospheric Administration/Pacific Marine Environmental Laboratory, USA.
}

\begin{abstract}
Characteristics of trace gases $\left(\mathrm{O}_{3}, \mathrm{CO}, \mathrm{CO}_{2}, \mathrm{CH}_{4}\right.$ and $\left.\mathrm{N}_{2} \mathrm{O}\right)$ and aerosols (particle size of 2.5 micron) were studied over the Arabian Sea, equatorial Indian Ocean and southwest part of the Bay of Bengal during the monsoon transition period (October-November, 2004). Flow of pollutants is expected from south and southeast Asia during the monsoonal transition period due to the patterns of wind flow which are different from the monsoon period. This is the first detailed report on aerosols and trace gases during the sampled period as the earlier Bay of Bengal Experiment (BOBMEX), Arabian Sea Monsoon Experiment (ARMEX) and Indian Ocean Experiments (INDOEX) were during monsoon seasons. The significant observations during the transition period include: (i) low ozone concentration of the order of $5 \mathrm{ppbv}$ around the equator, (ii) high concentrations of $\mathrm{CO}_{2}$, $\mathrm{CH}_{4}$ and $\mathrm{N}_{2} \mathrm{O}$ and (iii) variations in PM2.5 of $5-20 \mu \mathrm{g} / \mathrm{m}^{3}$.
\end{abstract}

\section{Introduction}

Emissions of trace gases and aerosols are increasing due to the fast industrialization in Asia, particularly in China and India. Studies on characteristics of atmospheric tropospheric ozone, $\mathrm{CO}$, $\mathrm{CO}_{2}, \mathrm{CH}_{4}$ and $\mathrm{N}_{2} \mathrm{O}$, and aerosols over the Indian Ocean subcontinent are rather sparse. The earlier measurements of trace gases and aerosols over the Indian Ocean have been carried out mostly during summer (Arabian Sea Monsoon Experiment, ARMEX (Sanjeeva Rao 2005), Bay of Bengal Monsoon Experiment, BOBMEX (Bhat et al 2001)) and winter monsoons (Indian Ocean Experiment: INDOEX). Observations during INDOEX (Ramanathan et al 2001) show the presence of a large haze layer over the Indian Ocean. Composition of this haze indicates that the continental outflow and long range transport are the major reasons for the pollutants to spread out over a large area of the Indian Ocean (Lelieveld et al 2001). No such detailed results are available during the monsoon transition period over the Arabian Sea and equatorial Indian Ocean. During monsoon periods, the wind is mainly meridional and the zonal wind is weaker over the equatorial Indian Ocean. October and November (withdrawal of monsoon period) are the months of transition when winds over the north Indian Ocean change from southwesterly to northerly and northeasterly bringing aerosols from south and southeast Asia to the equatorial and north Indian Ocean (Kunhikrishnan et al 2004).

Ozone acts as a major tropospheric greenhouse gas as well as a precursor of highly reactive hydroxy radical $(\mathrm{OH})$ that drives much of photochemistry in this atmospheric layer (Thompson 1992). The concentration of tropospheric ozone is mainly determined by its in situ photochemical production, downward transport from stratosphere,

Keywords. Trace gases; aerosols; Indian Ocean; monsoon transition; air pollutants. 
quasi-isentropic advection and surface destruction. Halocarbons also play a major role in the destruction of ozone over the ocean. The diurnal cycle of ozone over the ocean is largely governed by advection and destruction where photochemical production is less (de Laat and Lelieveld 2000). Carbon monoxide $(\mathrm{CO})$ is an important trace gas as it can produce or destroy ozone depending on the concentrations of NO- $\mathrm{NO}_{x}$ (Crutzen 1999). Because of the long lifetime of $\mathrm{CO}$ in the boundary layer, it is used as a good tracer of long range atmospheric transport (Dickerson et al 2002).

The measurements on surface ozone and $\mathrm{CO}$ over the Indian Ocean are very few, including those carried out under the Soviet American Gases and Aerosols Campaign (SAGA-II) and INDOEX campaign (Duli Chand et al 2001; Naja et al 1999; Lal et al 1998; Rhoads et al 1997). Recent measurements of atmospheric $\mathrm{CH}_{4}$ over the Indian Ocean include Rhoads et al (1997), as a part of the World Ocean Circulation Experiment (WOCE), and Naja et al (1999) and Gupta et al (1999) as a part of the INDOEX.

Airborne particles, in particular of the size of 2.5 micron, have the potential to increase both light scattering and light absorption in the atmosphere depending on their nature. Aerosols of this size can traverse long distances (Lelieveld et al 2001), and are therefore, treated as tracers of biomass burning. Moreover, these aerosols also have a large impact on health.

The present study is aimed at understanding the distribution and processes regulating trace gases and aerosols during the monsoon transition period. We present here the results obtained in campaign mode observations during the period, October 11 to November 16, 2004 onboard ORV Sagar Kanya. To identify the possible flow of pollutants, back trajectory analyses were done using the HYSPLIT4 model.

\section{Data and instrument details}

A UV-based analyzer (Model TECO-49C, Thermo Environmental Inc, Franklin, Massachusetts, USA) was used for measuring surface ozone. The precision of ozone measurement is $1 \mathrm{ppbv}$ with a detection limit of $1 \mathrm{ppbv}$ with a response time of 10 seconds for the entire period of observation. Calibration of the system is done regularly with the help of a built-in ozone generator. The analyzers incorporate corrections due to changes in temperature, pressure in the absorption cell and drift in the intensity of UV lamp. The data presented here are according to local solar time.

Measurements of $\mathrm{CO}$ were made using nondispersive infrared (NDIR) gas filter correlation analyzer (Model TECO-48CTL, Thermo Environmental Inc, Franklin, Massachusetts, USA). The analyzer operates on the principle of infrared absorption at $4.67 \mu \mathrm{m}$ vibration-rotation band of $\mathrm{CO}$. The lowest detection limit of the analyzer was 20 ppbv. The analyzer was inter-compared with API CO analyzer (Model API300) and calibrated with NIST traceable standard CO gas of $1 \mathrm{ppm}$ (M/s Praxair, USA) after cruise. The zero check is done every two hours using in-built zero air scrubber. The instrumental (TECO-48CTL) periodic zero drift is corrected before processing the data.

Collection of other trace gases $\left(\mathrm{CH}_{4}, \mathrm{~N}_{2} \mathrm{O}\right.$, $\mathrm{CO}_{2}$ ) was done by grab sampling, i.e., flushing the air through glass samplers. The glass samplers were flushed initially for ten minutes. After thorough flushing with ambient air, the air sample was collected above atmospheric pressure (to avoid contamination due to leakage) at the bow of the ship, when it is speeding ahead, and the sampler was locked. While collecting the samples, several precautions have been taken to avoid contamination. These samples were analyzed for $\mathrm{CH}_{4}, \mathrm{CO}_{2}$ and $\mathrm{N}_{2} \mathrm{O}$ in the laboratory at NPL, New Delhi, by gas chromatograph (Model Sigma2000 of Perkin-Elmer, USA) with FID and ECD detectors. A methanizer was used to reduce $\mathrm{CO}_{2}$ to $\mathrm{CH}_{4}$ before detection. The NIST traceable standard gases $\left(\mathrm{CH}_{4}\right.$ of $5.63 \mathrm{ppm}, \mathrm{CO}_{2}$ of $500 \mathrm{ppm}$ and $\mathrm{N}_{2} \mathrm{O}$ of $1.05 \mathrm{ppm} ; \mathrm{M} / \mathrm{s}$ Matheson Tri-Gas formerly Matheson Gas Products USA) were used for calibration. Nevertheless, some international comparison of these measurements and calibration would help to sort out observational biases, if any. A total of 43 air samples were collected along the cruise path.

The data on meteorological parameters (temperature, relative humidity, wind speed and wind direction) were obtained as a part of the buoy deployment program of NOAA/PMEL Tropical Atmospheric Ocean (TAO) Project. The details on types of sensors used and their accuracies are listed in table 1 (Freitag et al 2001; Lake et al 2003).

Samples of aerosols (fine particle size $2.5 \mu \mathrm{m}$ ) were collected on Whatman GF/A filters using a Fine Particle Sampler (Envirotech Pvt. Ltd., Delhi, APM-411). The suspended particulate matter (SPM) was collected by passing ambient air at a flow rate of $1.0-1.3 \mathrm{~m}^{3} /$ hour. The difference between the weight of filter paper before and after the sampling yielded the concentration of PM2.5. The sampling was done for a period of 24 hours.

To identify the regions of biomass burning, we have used the $\mathrm{CO}$ data from MOPITT instrument and also processed the fire data offered by MODIS (Moderate Resolution Imaging 
Table 1. Details of the instruments used for the study. It provides the sensor type, manufacturer, resolution, accuracy and range of the observation.

\begin{tabular}{|c|c|c|c|c|c|c|}
\hline Measurement & Sensor type & Manufacturer: model & Resolution & Range & Accuracy & Comments \\
\hline Ozone & $\begin{array}{l}\text { TECO-49 } \\
\text { UV-based }\end{array}$ & $\begin{array}{l}\text { Thermo Electron } \\
\text { Corporation, USA }\end{array}$ & $1 \mathrm{ppbv}$ & $0-1 \mathrm{ppm}$ & $1 \mathrm{ppbv}$ & \\
\hline $\begin{array}{l}\text { Carbon } \\
\text { monoxide }\end{array}$ & $\begin{array}{l}\text { TECO-48CTL } \\
\text { IR based }\end{array}$ & $\begin{array}{l}\text { Thermo Electron } \\
\text { Corporation, USA }\end{array}$ & $10 \mathrm{ppbv}$ & $0-10 \mathrm{ppm}$ & $20 \mathrm{ppbv}$ & \\
\hline $\begin{array}{l}\text { Air } \\
\text { temperature }\end{array}$ & $\begin{array}{l}\text { Pt-100 RTD } \\
\text { (resistance } \\
\text { recorder) }\end{array}$ & $\begin{array}{l}\text { Rotronic Instrument } \\
\text { Corp: MP-100 }\end{array}$ & $0.01^{\circ} \mathrm{C}$ & $0-40^{\circ} \mathrm{C}$ & $\pm 0.2^{\circ} \mathrm{C}$ & Lake et al 2003 \\
\hline $\begin{array}{l}\text { Relative } \\
\text { humidity }\end{array}$ & Capacitance & $\begin{array}{l}\text { Rotronic Instrument } \\
\text { Corp: MP-100 }\end{array}$ & $\begin{array}{l}0.4 \% \mathrm{RH} \text { real } \\
\text { time } 0.02 \% \mathrm{RH} \\
\text { delay mode }\end{array}$ & & $\pm 2.7 \% \mathrm{RH}$ & Lake et al 2003 \\
\hline $\begin{array}{l}\text { Wind } \\
\text { direction }\end{array}$ & Propeller & R.M.Young 05103 & $0.2 \mathrm{~m} / \mathrm{s}$ & & $\pm 0.3 \mathrm{~m} / \mathrm{s}$ & Freitag et al 2001 \\
\hline Wind speed & Vane & R.M.Young 05103 & $1.4^{\circ}$ & $0-355$ & $\pm 5-7.8^{\circ}$ & Freitag et al 2001 \\
\hline
\end{tabular}

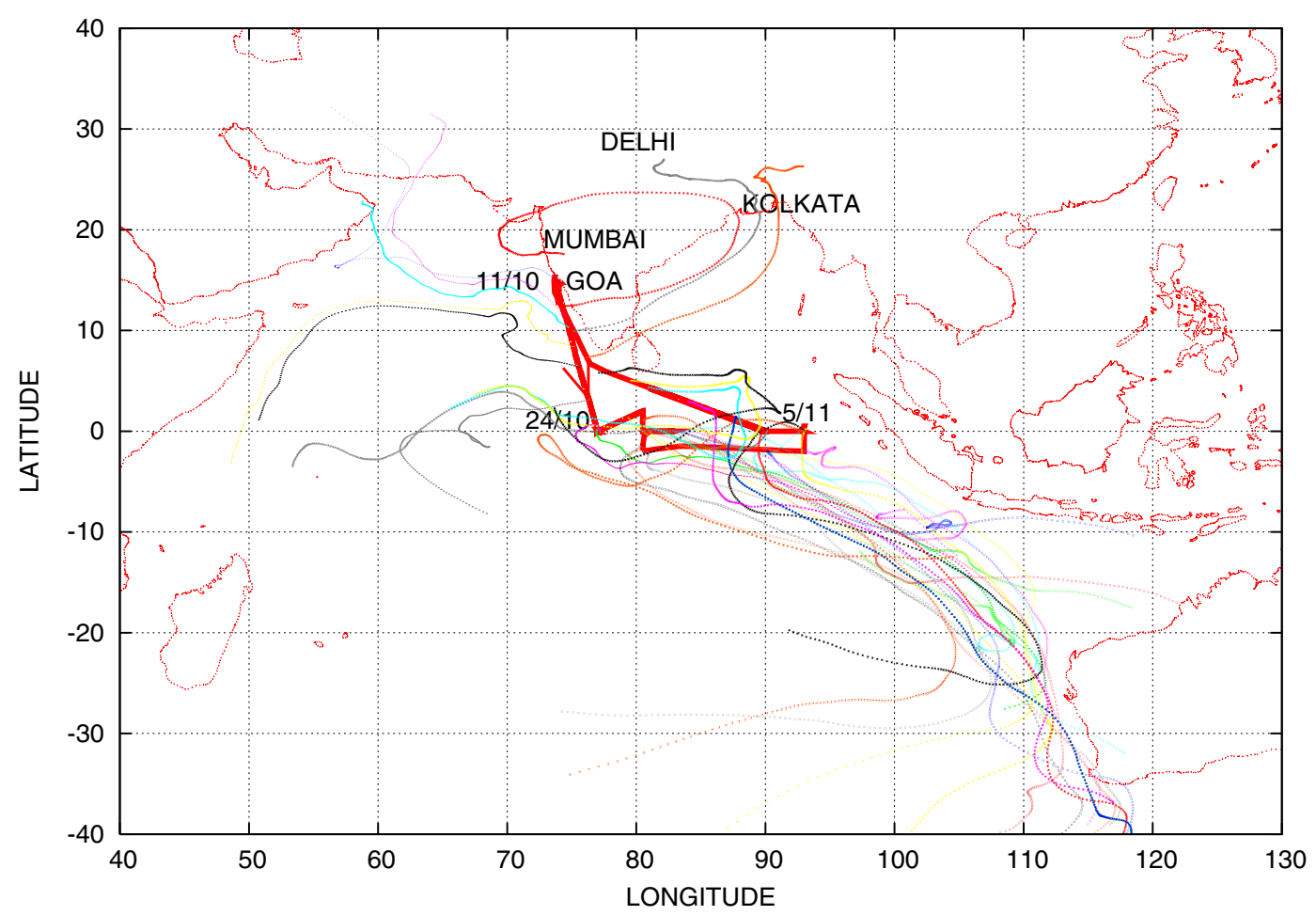

Figure 1. Cruise track and air mass trajectories during this study. The thick line represents the position of ORV Sagar Kanya. Thin lines are 10-day back trajectories obtained using HYSPLIT-4 model starting each day at 12:00 hours Local Solar Time at the ship's position.

Spectroradiometer). MOPITT measures the upwelling infrared radiance at wavelengths $4.7 \mu \mathrm{m}$ and $2.3 \mu \mathrm{m}$ onboard NASA EOS Terra satellite at a height of $705 \mathrm{~km}$ (Drummond et al 1996). We have used $\mathrm{CO}$ mixing ratio at $850 \mathrm{hPa}$. The methodology of CO retrievals from radiance measurements has been discussed elsewhere in detail (Deter et al 2003).

Each of these fire maps shows the locations of the fires detected by MODIS onboard the Terra and Aqua satellites over a 10-day period (Giglio et al 2003). The data of MODIS are based on the measurement of 36 spectral bands between 0.405 and $14.385 \mu \mathrm{m}$. These climatological data are available from March 2000 (http://rapidfire.sci.gsfc.nasa.gov/firemaps/).

\section{Ship tracks and meteorology}

Figure 1 shows cruise tracks of ORV Sagar Kanya (SK 212) with air mass backward trajectories over 


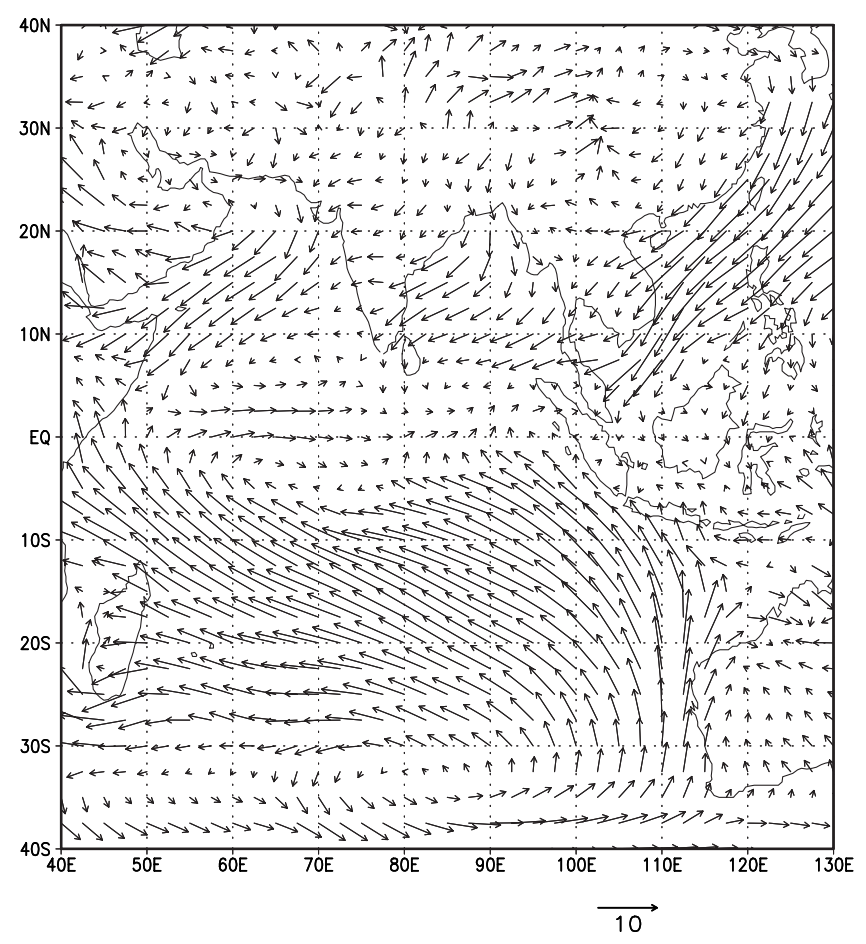

Figure 2. Plot of NCEP/NCAR reanalysis of horizontal wind fields at $2.5 \times 2.5$ degree resolution averaged over the entire cruise period (October 11 to November 17, 2004) over the region $40^{\circ} \mathrm{N}$ to $40^{\circ} \mathrm{S}$ and $40^{\circ} \mathrm{E}$ to $130^{\circ} \mathrm{E}$. The arrow shown below indicates wind speed of $10 \mathrm{~m} / \mathrm{s}$.

the Indian Ocean. Ten days air mass back trajectories were calculated with the HYSPLIT (HYbrid Single-Particle Lagrangian Integrated Trajectory) model (Draxler and Rolph 2003) using FNL as meteorological input data. Meteorological data used were collected onboard Sagar Kanya.

Figure 2 presents NCEP/NCAR reanalysis of wind fields at a resolution of $2.5 \times 2.5$ degree averaged over the entire cruise period (October 11 to November 17, 2004) over the region. Based on the wind flow pattern, the entire cruise period may be divided into three regimes of air parcel movement. During the onward journey, i.e., over the Arabian Sea, wind at surface was mostly northeasterly and upper wind westerly, therefore, air mass originated from the Arabian Sea until ship reached the equator. Once the ship started moving along the equator, the wind was either easterly or southeasterly and hence the air masses originated from south Asia and the Australian subcontinent. On the return journey, flow is north and northeasterly and trajectory calculation shows that air masses originated from the south and southeast Asia. Along the coastal region air mass was mostly from the Indian subcontinent. The measured wind onboard ORV Sagar Kanya indicates that the zonal wind (u) had dominated over the meridional wind (v) up to the equator (figure 3). This is consistent with the NCEP/NCAR reanalysis and general features of the monsoon transition period. Along the equator, both the meridional wind and zonal wind are very low as observed in the NCEP reanalysis. It may also be pointed that most of the cruise period experienced rainfall.

\section{Results and discussion}

\subsection{Variation of ozone and its relationship with carbon monoxide}

The daily averaged concentrations of ozone, carbon monoxide and relative humidity measured along the cruise path is shown in figure 4 . It may be seen that near the coast the ozone concentration was around $16 \mathrm{ppbv}$ and decreased sharply to $7 \mathrm{ppbv}$ and increased to $10 \mathrm{ppbv}$ on October 16, 2004 and then the concentration varied around 10 ppbv. From November 13 ozone concentration showed an increase up to $20 \mathrm{ppbv}$. Ozone concentration at Bukit Koto $\left(0.2^{\circ} \mathrm{S}, 100.31^{\circ} \mathrm{E}\right)$, an east Asian station, shows concentration of the order of 10-20 ppbv. Our result is consistent with the observation of Stehr et al (2002), whereas, Naja et al (1999) and Duli Chand et al (2001) reported ozone concentration as high as $50-100$ ppbv near the coast during INDOEX. Johnson et al (1990) and Duli Chand et al (2001) have also found very low ozone of $4 \mathrm{ppbv}$ near the equator. In addition, Naja et al (1999) observed a latitudinal gradient of $1.5 \mathrm{ppbv} /$ lat., which is not found in the present study. Results obtained during INDOEX (Lal et al 1998; Stehr et al 2002; Lelieveld et al 2001; Rhoads et al 1997) suggested that the region over the northern Indian Ocean is heavily polluted with aerosols and volatile organic carbon (VOC). The low value of ozone could be due to the presence of low $\mathrm{NO}_{x}$ concentration over the Indian Ocean (Lal et al 1998). The role of prevailing dynamics appears important for sustaining the gradients in trace constituents.

During the onward journey the concentration of CO was $220 \mathrm{ppbv}$ which decreased to $100 \mathrm{ppbv}$ near the equator and then remained between 100 and $150 \mathrm{ppbv}$. However, on the return journey, $\mathrm{CO}$ reached up to $280 \mathrm{ppbv}$ near the coast (figure 4). Naja et al (1999) have observed CO concentrations to be between 200 and $350 \mathrm{ppbv}$ in the region from equator to $15^{\circ} \mathrm{N}$. Duli Chand et al (2001) observed a similar feature during the final phase of the INDOEX. Stehr et al (2002) have found the CO concentration up to a maximum of $200 \mathrm{ppbv}$ in the Arabian Sea and $150 \mathrm{ppbv}$ in the Bay of Bengal. Changes in relative humidity (figure 4) suggest that continental outflow from the Indian subcontinent resulted in the high values of $\mathrm{CO}$ near the coastal region. During the observational period, 

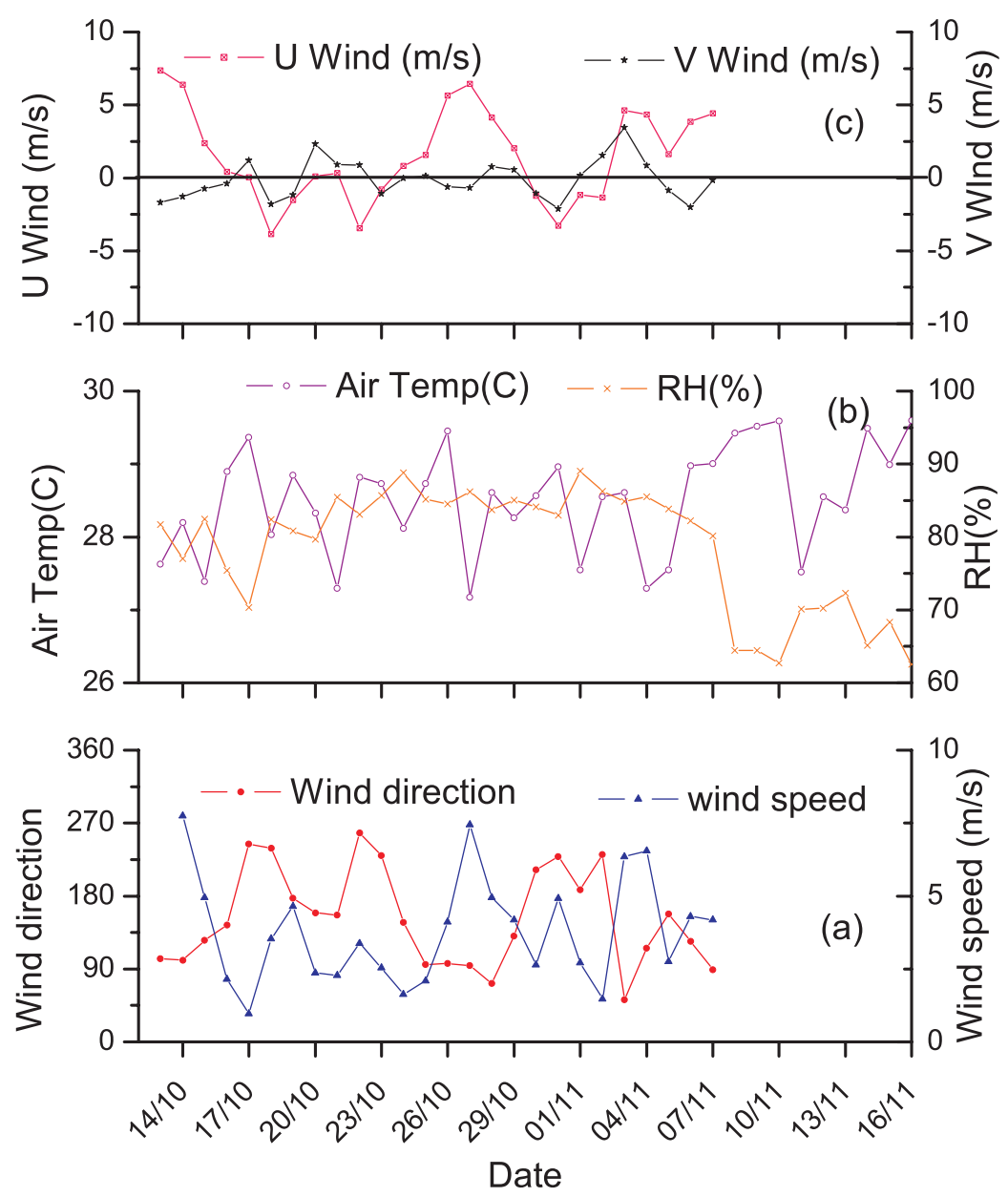

Figure 3. Variations in meteorological parameters observed during cruise period. (a) wind speed (solid triangle) and wind direction (solid circle), (b) relative humidity (\%) (cross) and air temperature (open circle) and (c) zonal wind (U) (crossed square) and meridional wind (V) (star).

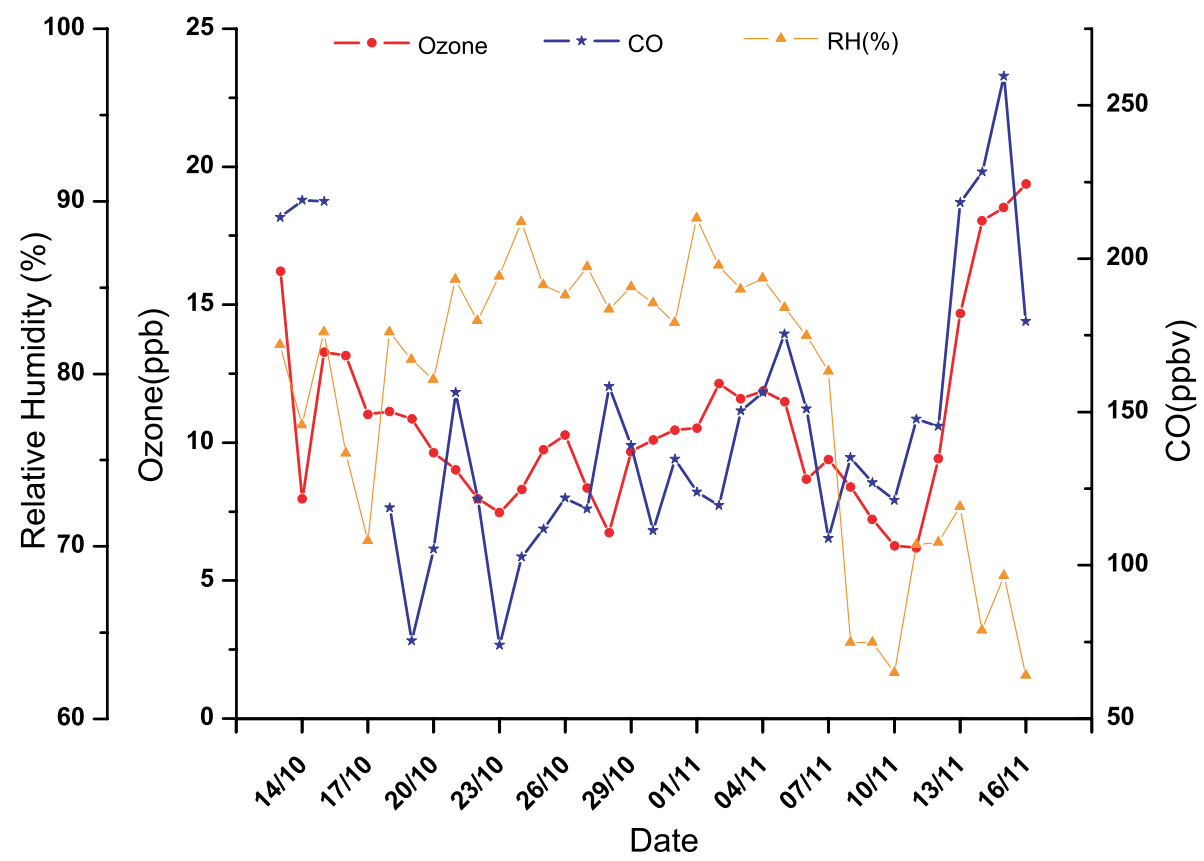

Figure 4. Variations in ozone (solid circle), CO (star) and relative humidity (solid triangle) observed during the cruise. Onward journey of the ship from October 11, 2004 to October 24, 2004, along the equator from October 24, 2004 to November 5, 2004 and return leg from November 5, 2004 to November 17, 2004. 


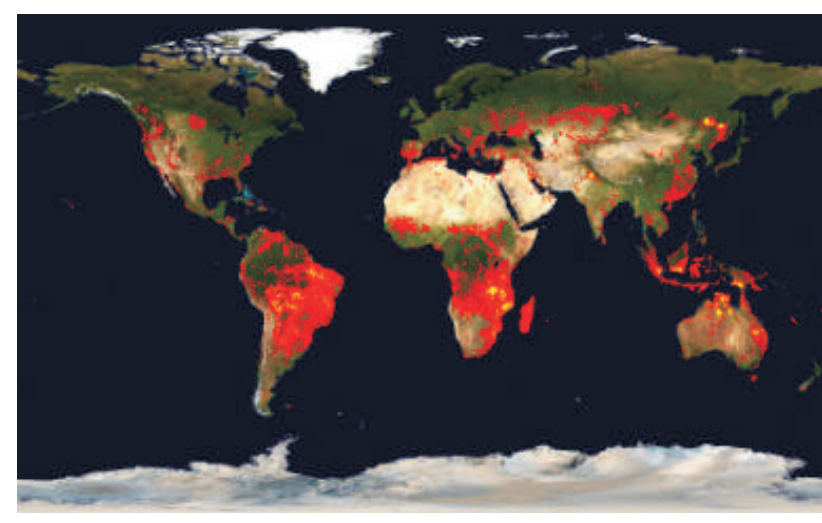

DOY $281-290$

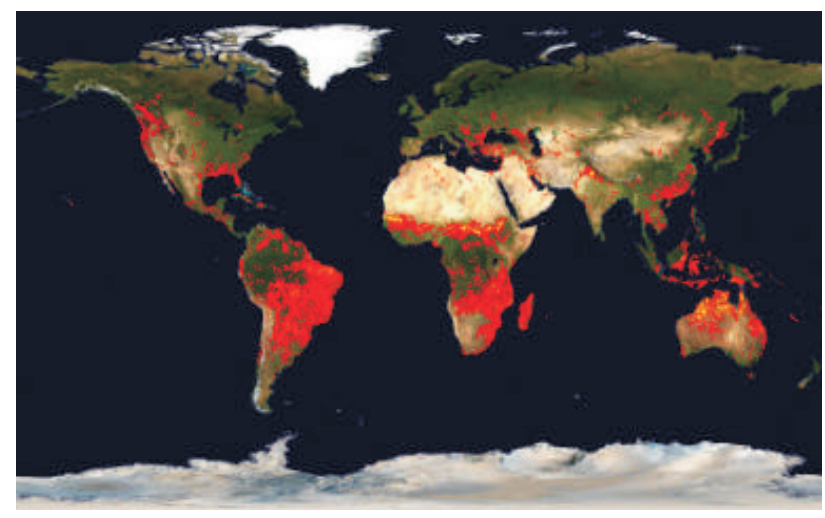

DOY $301-310$

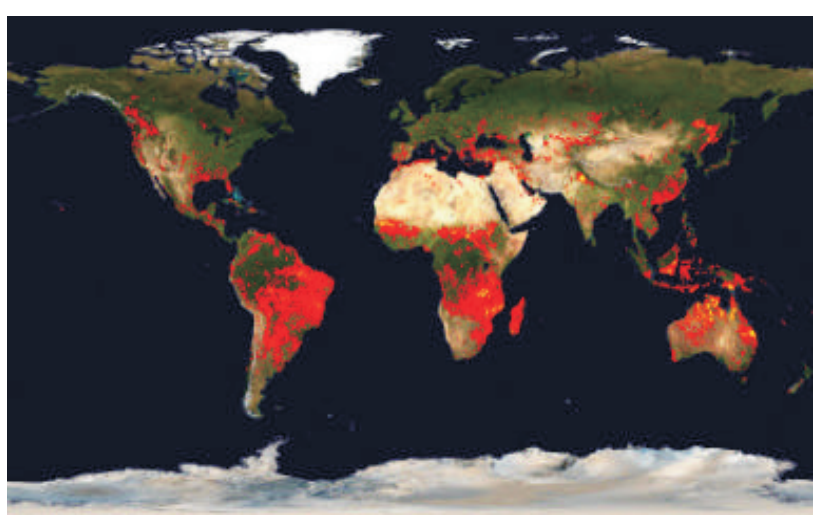

DOY $291-300$

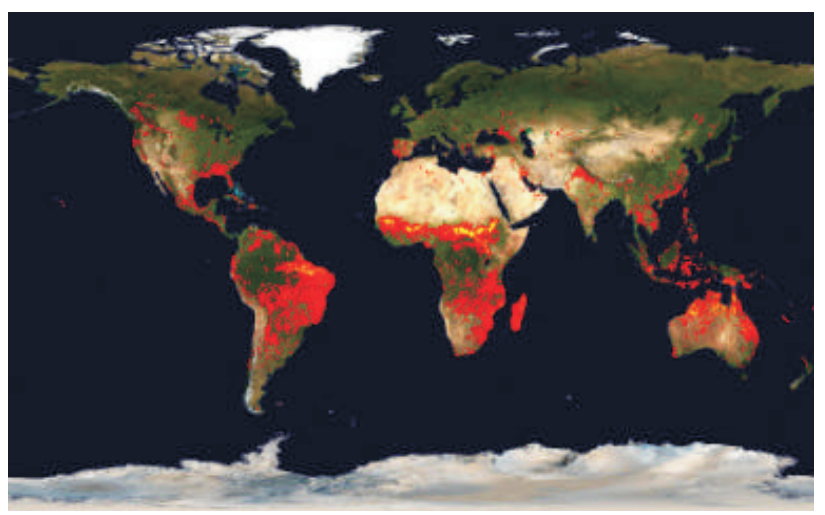

DOY $311-320$

Figure 5. Global fire maps averaged over 10 days obtained from processed MODIS data. Fire maps are created at MODIS Rapid Response System at NASA/GSFC. Each of these fire maps shows the locations of fires detected by MODIS onboard the Terra and Aqua satellites. Each coloured dot indicates a location where MODIS detected at least one fire during the compositing period. Colour ranges from red where the fire count is low to yellow where the number of fires is large. The compositing periods are identified by their start and end dates (julian day).

moderate biomass burning events occurred in south and southeast Asia as shown by MODIS data (figure 5). MOPITT data at $850 \mathrm{hPa}$ also shows the presence of high $\mathrm{CO}$ concentration $(<250 \mathrm{ppbv})$ over the same region (figure 6). Backward trajectories show that air masses have mainly originated from south and southeast Asia regions (figure 1). Convection and lightning are very active over Indonesia during the monsoon transition periods, especially during September (Kita et al 2003). Nevertheless there is a large interannual variability with enhanced biomass burning during dry El-Niño periods (e.g., September-October, 1997). Dickerson et al (2002) have also related high concentration of $\mathrm{CO}$ observed over the Indian Ocean to continental outflow from India (emission of CO, $67 \mathrm{Tg} / \mathrm{yr}$ ) and southeast Asia (emission of $\mathrm{CO}$, $87 \mathrm{Tg} / \mathrm{yr})$.

Figure 7 depicts the diurnal cycle of ozone, $\mathrm{CO}$ and relative humidity averaged over the observational period. Although ozone does not show much diurnal variation (8-12 ppbv CO shows significant changes $(120-160 \mathrm{ppbv}))$, it is to be noted that the time of maximum may not be true as it has been averaged over the region from $92^{\circ} \mathrm{E}$ to $72^{\circ} \mathrm{E}$. Ozone and relative humidity are strongly negatively correlated with $\mathrm{CO}$, particularly during daytime. $\mathrm{CO}$ normally acts as a precursor of ozone but about $70 \%$ of $\mathrm{OH}$ is expected to react with CO (Wanye 1991). Parrish et al (1998) observed a positive correlation between ozone and $\mathrm{CO}$ while Derwent et al (1994) found a negative correlation. Since CO has a lifetime of the order of a month, diurnal variation of $\mathrm{CO}$ could be modulated by its long range transport from south and southeast Asia.

\subsection{Relationship between PM2.5 and meteorological parameters}

Figure 8 shows the variations in aerosol particle size of $2.5 \mu \mathrm{m}$, relative humidity, wind speeds 
MOPIT CO (V3) 850hPa Oct 1-30, 2004

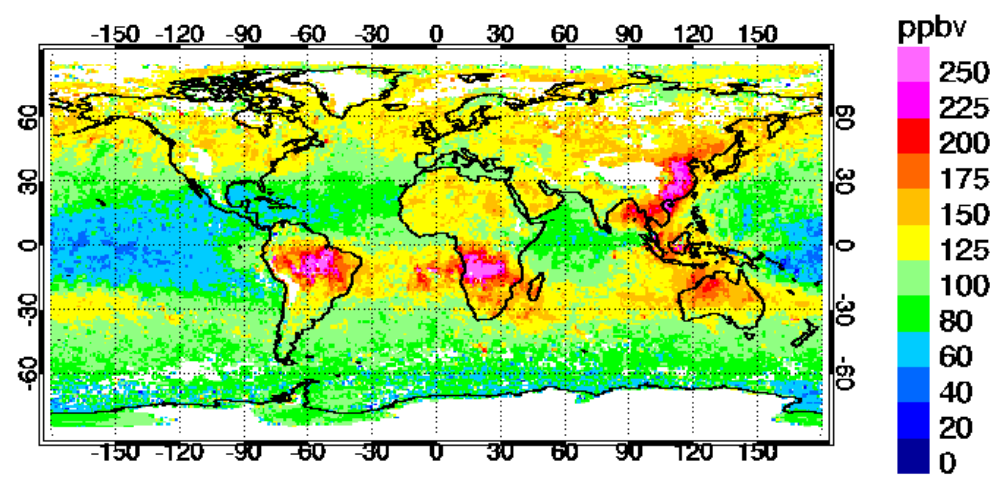

MOPIT CO (V3) 850hPa Nov 1-30, 2004

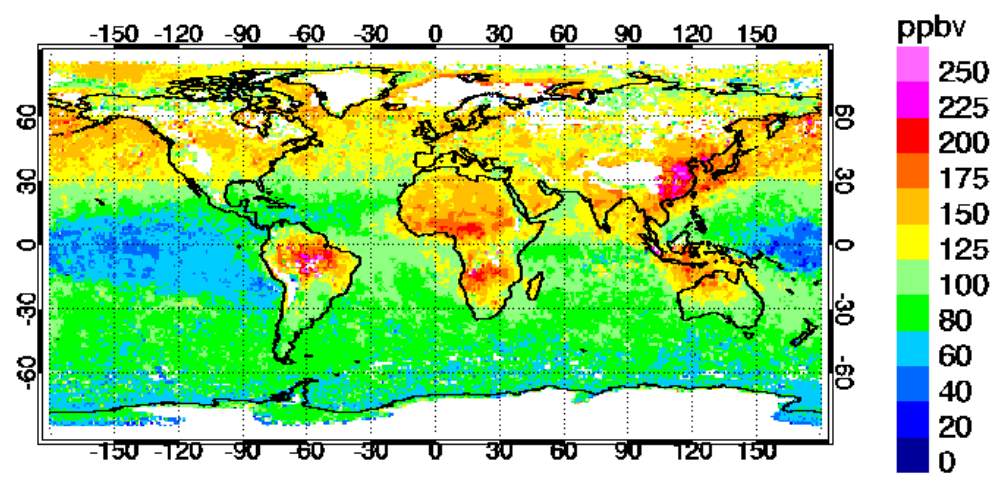

Figure 6. Plot of geographical distribution of carbon monoxide data at $850 \mathrm{hPa}$ obtained through MOPITT satellite. The colour scale on the right side gives the concentration ranges of carbon monoxide. Upper panel shows the averaged CO distribution for the month of October 2004 and the lower panel for the month of November 2004.

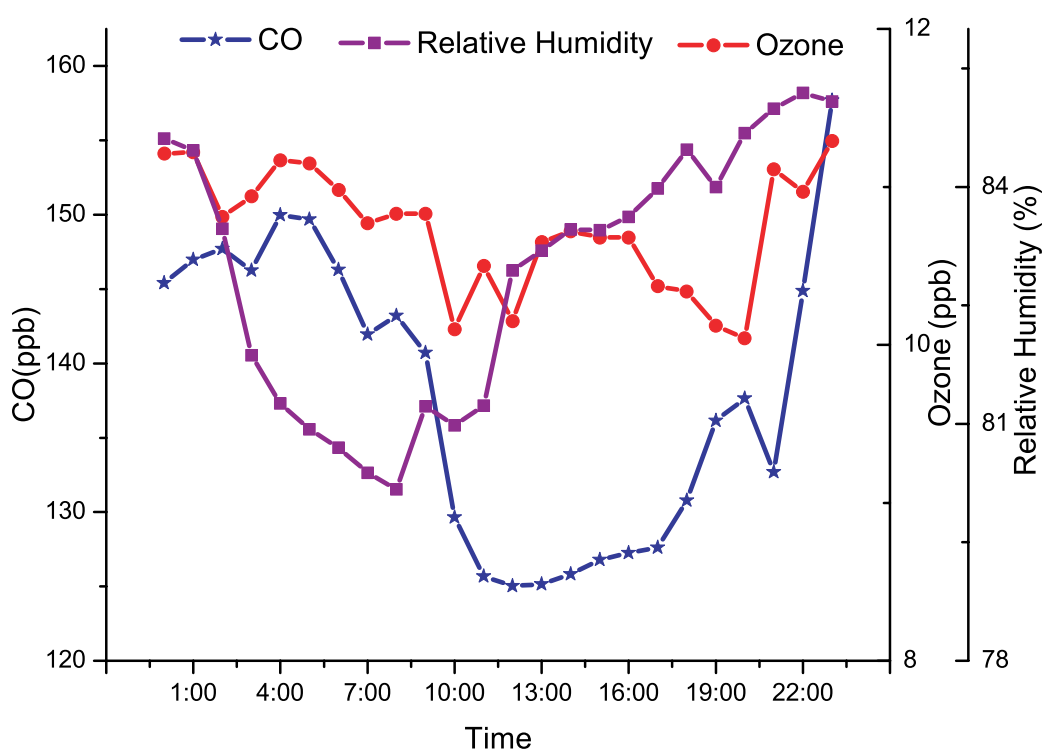

Figure 7. The diurnal cycle of ozone (solid circle), CO (star) and relative humidity (\%) (solid square) averaged over the entire cruise period.

observed along the cruise path. The wind speed is positively correlated to aerosol particle size of $2.5 \mu \mathrm{m}$. The variation of these particles was within $5-20 \mu \mathrm{g} / \mathrm{m}^{3}$ except near the equator, where its concentration reached $37 \mu \mathrm{g} / \mathrm{m}^{3}$ when wind speed was quite high. Large amounts of sea spray because of high wind $(7.4 \mathrm{~m} / \mathrm{s})$ might have been collected on the filter paper. Moreover, the highest value 


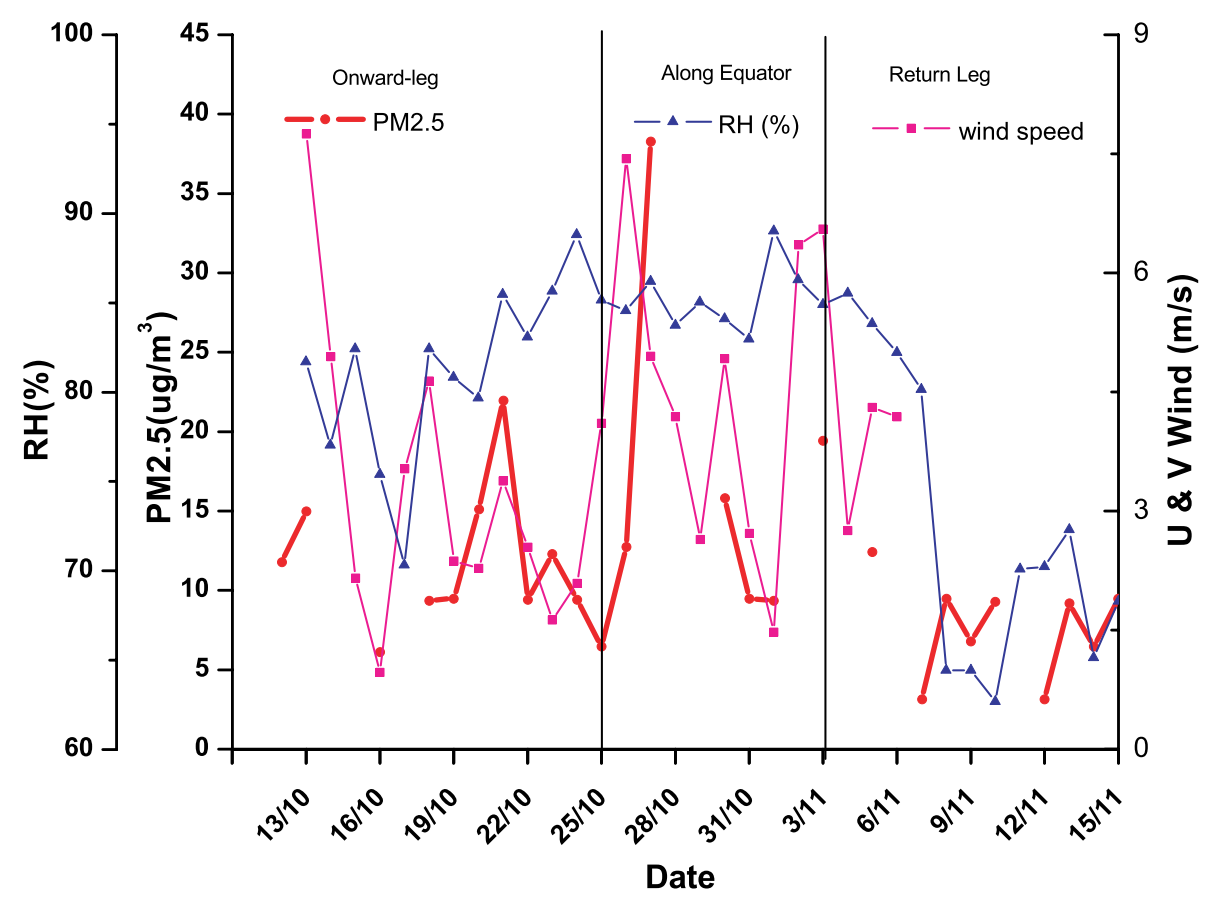

Figure 8. Daily variations of aerosol particle (PM2.5) (solid circle), relative humdity (\%) (solid triangle) and wind speed (solid square) size measured along the cruise path. The periods of onward journey along the equator and return leg are the same as detailed in figure 4.

of PM2.5 on October 26-27 could be attributed to long range transport, as air mass back trajectory shows that it had originated from the area of biomass burning (figure 1). During the return leg, even near the coast, the concentration of PM2.5 dropped to $10 \mu \mathrm{g} / \mathrm{m}^{3}$. It is surprising to note that relative humidity too has come down from $80 \%$ to $60 \%$. Relative humidity did not show any variation during the onward journey and along the equator. Chemical composition of these samples may offer better explanation of variation of aerosol concentration. Krishnamurthi et al (1998) had also observed fine particle concentration of the order of $15.8 \mu \mathrm{g} / \mathrm{m}^{3}$ in the regional plume, which might have been advected to the Indian Ocean during the northeast monsoon. Choudhary et al (2001) have shown that the PM2.5 at Kashidoo Climate Observatory $(\mathrm{KCO})$ varied in the range $15-30 \mu \mathrm{g} / \mathrm{m}^{3}$ during winter monsoon time. They have also shown that the sulfate and carbonaceous aerosols are the largest contributors to these fine particles. Ramachandran (2005) has reported background PM2.5 mass concentration of the order 36 and $25 \mu \mathrm{g} / \mathrm{m}^{3}$ over the Arabian Sea and tropical Indian Ocean using the data collected in the northeast winter monsoon seasons of 1996 and 2000, respectively.

\subsection{Variation of GHGs}

The distributions of $\mathrm{CH}_{4}, \mathrm{CO}_{2}, \mathrm{~N}_{2} \mathrm{O}$ at surface along the cruise path are shown in figure 9 .
Table 2 also gives a comparison between the results obtained in the present and the earlier studies. On an average, the results obtained during the present cruise are higher than earlier reported. The role of contamination in the air samples during the sampling is ruled out as higher values in $\mathrm{CH}_{4}, \mathrm{CO}_{2}$, $\mathrm{N}_{2} \mathrm{O}$ are not observed simultaneously.

The observed concentration of methane is higher than that earlier reported in the northern hemisphere (1.8 ppmv) (Muhle et al 2002). The average concentration of methane ranged from 1.69 to $2.7 \mathrm{ppmv}$. This value is higher than the observed concentration during INDOEX (Naja et al 1999; Duli Chand et al 2001; Gupta et al 1999 and Muhle et al 2002). However, Lal et al (2006) found high concentrations of $\mathrm{CH}_{4}$ in the Bay of Bengal to the order of $2.1 \mathrm{ppmv}$ during the early spring of 2001. Near the coast, $\mathrm{CH}_{4}$ was observed to be $\sim 2.0 \mathrm{ppmv}$, which increased to $2.86 \mathrm{ppmv}$ at the equator with a latitudinal gradient $-0.06 \mathrm{ppmv} /$ lat. Naja et al (1999) observed that the average gradient of methane concentrations is around $0.0006 \mathrm{ppmv} /$ lat during the pre-INDOEX cruise of 1997 and 1998, whereas, the average gradient during 1999 was found to be $0.0003 \mathrm{ppmv} /$ lat. (Duli Chand et al 2001). Although, ocean is normally considered to be a minor source of global tropospheric $\mathrm{CH}_{4}$, extensive measurements made by several scientists in the Arabian Sea and coastal India (Lal et al 1996; Patra et al 1998; Bange et al 1998; Jayakumar et al 2001) revealed strong 


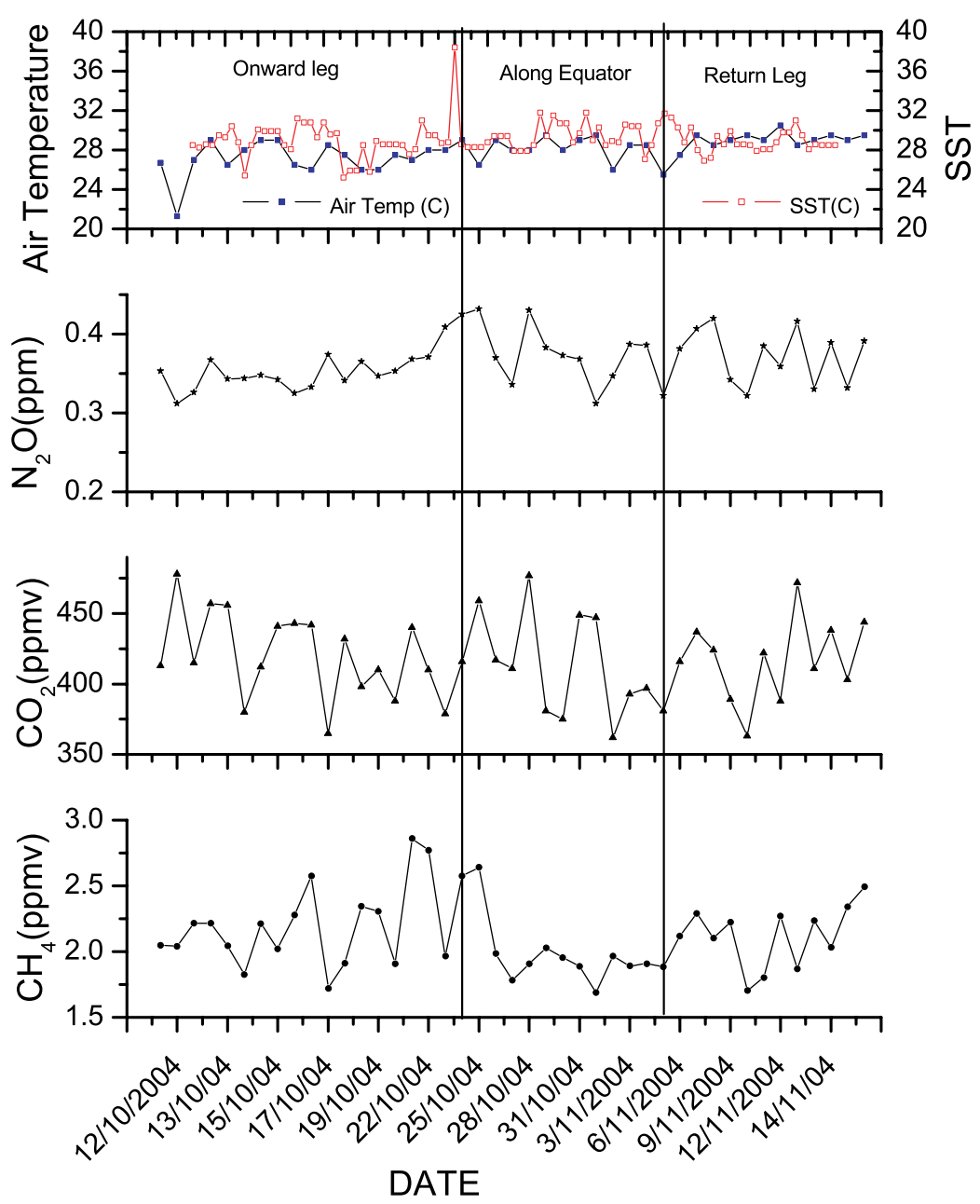

Figure 9. Variations of $\mathrm{CH}_{4}$ (solid circle), $\mathrm{CO}_{2}$ (solid triangle), $\mathrm{N}_{2} \mathrm{O}$ (star) and air temperature (solid square) and SST (open square) observed during the cruise. The periods of onward journey along the equator and return leg are the same as detailed in figure 4.

spatial, seasonal and interannual variability of $\mathrm{CH}_{4}$.

The concentrations of $\mathrm{CO}_{2}$ along the cruise were found to be in the range $362-477 \mathrm{ppmv}$, which is also higher than observed values during INDOEX (Gupta et al 1999; Muhle et al 2002). High variation of $\mathrm{CO}_{2}$ concentration of the order of 100 ppmv within short time scale is normally unexpected, but, no observations are available to compare this result. It may be noted that such variation has only been reported by Mukhopadhyay et al (2002), where, they showed $\mathrm{CO}_{2}$ concentration of 324.3 to $528.7 \mathrm{ppmv}$ in the Sunderban area, $\mathrm{NE}$ coast of Bay of Bengal. $\mathrm{CO}_{2}$ concentration reached minimum value $365 \mathrm{ppmv}$ at the equator with a latitudinal gradient of $1 \mathrm{ppmv} / \mathrm{lat}$. but increased again to $477 \mathrm{ppmv}$. The positive latitudinal gradient observed during onward and return journeys is consistent with the results obtained during pre-INDOEX and final phase of INDOEX by Muhle et al (2002) and Gupta et al (1999).
JGOFS studies concluded that the Arabian Sea serves as a source of $\mathrm{CO}_{2}$ for the atmosphere at almost all places and during all seasons with large variability, whereas, the observations in the Bay of Bengal and the Andaman Sea show that it is a weak sink $\left(\sim 20 \mathrm{Tg} \mathrm{C} \mathrm{y}^{-1}\right)$ for atmospheric $\mathrm{CO}_{2}$ (Kumar et al 1996; Sarma et al 2000; Naqvi et al 2005). The 10-day backward trajectories over the Arabian Sea (figure 1) show that the origin of air parcel is oceanic, whereas, the air mass originated from south and southeast Asia, area of biomass burning during the equator and return leg (figures 5 and 6 ). At this moment, it is difficult to say definitely, with the present limited atmospheric observations that this high $\mathrm{CO}_{2}$ concentrations over Arabian Sea are of oceanic origin because of its large lifetime. Sarma et al (2000) have argued that bacteria found in seawater are more abundant during intermonsoon period that are not entirely supported by primary production and hence the resultant higher bacterial respiration may raise $\mathrm{pCO}_{2}$ levels in the ocean. The Sea Surface Temperature (SST) 
is found to vary from $28^{\circ}$ to $32^{\circ} \mathrm{C}$ (figure 9 ) and is mostly higher than the air temperature, which varied within $24-28^{\circ} \mathrm{C}$. The higher temperature gradient might have facilitated release of $\mathrm{CO}_{2}$ and $\mathrm{N}_{2} \mathrm{O}$ to the atmosphere.

The concentration of $\mathrm{N}_{2} \mathrm{O}$ near the coast, as depicted in figure 9, was $312 \mathrm{ppbv}$ but reached a maximum of $432 \mathrm{ppbv}$ at the equator with a latitudinal gradient of $2 \mathrm{ppbv} /$ lat. $\mathrm{N}_{2} \mathrm{O}$ concentration then has decreased sharply to $312 \mathrm{ppbv}$ again after the ship entered southern hemisphere. $\mathrm{N}_{2} \mathrm{O}$ concentration does not change substantially along the equator and in the return leg. Surprisingly, the maximum concentration of $\mathrm{N}_{2} \mathrm{O}$ matches with position of maximum concentration of $\mathrm{CO}_{2}$. Gupta et al (1999) have not observed any latitudinal gradient in their study during the three pre-INDOEX cruises. With the present data it is difficult to suggest that this high concentration of nitrous oxide is due to upwelling of oceanic water. JGOFS Arabian Sea data show that sea-to-air fluxes of $\mathrm{N}_{2} \mathrm{O}$ over the Arabian Sea are higher particularly in the south Indian coastal region with strong temporal variability (Lal and Patra 1998; Naqvi et al 1998; Patra et al 1999). Total estimates of $\mathrm{N}_{2} \mathrm{O}$ fluxes from the Arabian Sea to the atmosphere ranges between 0.16 and $1.5 \mathrm{Tg} \mathrm{N}_{2} \mathrm{O} \mathrm{y}^{-1}$. Naqvi et al (2000) suggested that anomalous concentration of $\mathrm{N}_{2} \mathrm{O}$ in the Arabian Sea could be driven by anthropogenic origin. However, from the present study, we cannot conclude that high concentration of atmospheric $\mathrm{N}_{2} \mathrm{O}$ is of oceanic origin.

\section{Summary and conclusion}

Characteristics of atmospheric surface ozone, $\mathrm{CO}$, $\mathrm{CH}_{4}, \mathrm{~N}_{2} \mathrm{O}, \mathrm{CO}_{2}$ and aerosol (fine particles) were studied over the Bay of Bengal, the Arabian Sea and the equatorial Indian Ocean during the monsoon transition period, i.e., October-November, 2004.

The following features were found during the campaign:

- The wind flow patterns during monsoon transition period are different from that of monsoons as found from NCEP/NACR reanalysis and onboard measured meteorological parameters. The 10-day backward trajectories suggest that origin of air parcel found over the Arabian Sea is mostly over the ocean, whereas those above the equator and during the return journey are from south or southeast Asia.

- Surface ozone concentration is maximum near coastal region and minimum near equator. No substantial meridional changes are observed in ozone concentrations. 
- Carbon monoxide concentration shows similar feature with maximum value near the coast and lowest value near the equator. The observed trend is consistent with the earlier reported results. The role of long range transport from south Asia and southeast Asia, which are regions of biomass burning as seen in MOPITT and MODIS data, is examined.

- The study region is important in terms of sea-toair exchange of biogenic gases. No atmospheric observation of $\mathrm{CH}_{4}, \mathrm{CO}_{2}$ and $\mathrm{N}_{2} \mathrm{O}$ is available during monsoon transition period; therefore, comparative study is not possible at this stage. Large variations of $\mathrm{CH}_{4}, \mathrm{CO}_{2}$ and $\mathrm{N}_{2} \mathrm{O}$ concentration over short time scale are however unexpected.

- During onward journey from $15^{\circ} \mathrm{N}$ to equator, $\mathrm{CH}_{4}$ and $\mathrm{N}_{2} \mathrm{O}$ show prominent negative gradients, and $\mathrm{CO}_{2}$ shows positive gradient, whereas, on the return leg $\mathrm{CH}_{4}$ and $\mathrm{CO}_{2}$ show positive latitudinal gradients, but $\mathrm{N}_{2} \mathrm{O}$ concentration does not show such trend. Since the Arabian Sea is normally known as a region of biogenic gases emitter, the enhanced concentration of atmospheric $\mathrm{CH}_{4}$ and $\mathrm{N}_{2} \mathrm{O}$ over Arabian Sea might be due to emission from ocean. The enhanced values over the Bay of Bengal and the equator appear to be linked to biomass burning over east Asia and south east Asia.

- The mass concentration of PM2.5 varied within $5-20 \mu \mathrm{g} / \mathrm{m}^{3}$ except near the equator, where the value reached $37 \mu \mathrm{g} / \mathrm{m}^{3}$. Relative humidity and wind speed are strongly correlated with high concentration of PM2.5. Chemical analysis of these samples may give more insight into reasons that caused high concentrations.

\section{Acknowledgements}

Authors are grateful to the Director, National Physical Laboratory, New Delhi for his support. Authors are thankful to CSIR for funding this program under CSIR-Network Activity. Authors acknowledge the TAO Project Office, National Oceanic and Atmospheric Administration, Pacific Marine Environmental Laboratory, USA. The National Institute of Oceanography, Goa is thankfully acknowledged for providing the opportunity to participate in the Buoy Deployment cruise, SST data and logistic support while staying at Goa. The authors also acknowledge the NOAA Air Resources Laboratory (ARL) for permitting the use of their HYSPLIT transport and dispersion model and/or READY website (http://www.arl.noaa.gov/ready.html) results used in this publication. We further acknowledge the NOAA-CIRES Climate Diagnostics Center for the reanalysis data provided at their website at http://www.cdc.noaa.gov/. This is NIO contribution no. 4143.

\section{References}

Bange H W, Ramesh R, Rapsomanikis S and Andreae M O 1998 Methane in surface waters of the Arabian Sea; Geophys. Res. Lett. 25 3547-3550.

Bhat J S et al 2001 BOBMEX: The Bay-of-Bengal Monsoon Experiment, Bull. Amer. Meteor. Soc. 82 2217-2243.

Choudhary Z, Huges L S, Salmon L G and Cass G R 2001 Atmospheric particle size and composition measurements to support light extinction calculations over the Indian Ocean; J. Geophys. Res. 106(D22) 28,597-28,605.

Crutzen P J, Lawrence M G and Poschl U 1999 On the background photochemistry of tropospheric ozone; Tellus Ser A 51 123-146.

Dickerson R R, Andreae M O, Campos T, Mayol-Bracero O L, Neusuess C and Streets D G 2002 Analysis of black carbon and carbon monoxide observed over the Indian Ocean: Implications for emissions and photochemistry; J. Geophys. Res. 107(D19) 8017, doi:10.1029/2001JD000501.

de Laat A T J and Lelieveld J 2000 Diurnal ozone cycle in the tropical and subtropical marine boundary layer; J. Geophys. Res. 105(D9) 11,547-11,559.

Derwent R G, Simmonds P G and Collins W J $1994 \mathrm{O}_{3}$ and $\mathrm{CO}$ measurements at a remote maritime location, Mace Head, Ireland, from 1990 to 1992; Atmos. Environ. 28(16) 2623-2637.

Deter M N et al 2003 Operational carbon monoxide retrieval algorithm and selected results for the MOPITT instruments; J. Geophys. Res. 106(D14) 4399.

Draxler R R and Rolph G D 2003 HYSPLIT (HYbrid Single-Particle Lagrangian Integrated Trajectory) Model access via NOAA ARL READY Website (http://www.arl.noaa.gov/ready/hysplit4.html). NOAA Air Resources Laboratory, Silver Spring, MD.

Drummond, James R and Mand G S 1996 The measurements of pollution in the troposphere (MOPITT) Instrument: Overall performance and Calibration Requirements, Journal of Atmospheric and Oceanic Technology 13314.

Duli Chand, Modh K S, Naja M, Venkataramani S and Shyam Lal 2001 Latitudinal trends in $\mathrm{O}_{3}, \mathrm{CO}, \mathrm{CH}_{4}, \mathrm{SF}_{6}$, over the Indian Ocean during the INDOEX IFP-1999 ship cruise; Curr. Sci. 80 (supplement) 100-104.

Freitag H P, O'Haleck M, Thomas G C and McPhaden M J 2001 Calibration procedures and instrumental accuracies for ATLAS wind measurements, NOAA Tech Memo. OAR PMEL-119, NOAA/Pacific Marine Environmental Laboratory, Seattle, Washington, $20 \mathrm{pp}$.

Giglio L, Descloitres J, Justice C O and Kaufman Y J 2003 An enhanced contextual fire detection algorithm for MODIS; Remote Sensing of Environment 87 273-282.

Gupta, Prabhat K, Sharma C, Koul S, Parashar D C, Mandal T K and Mitra A P 1999 Study of trace gas species including greenhouse gases over the Indian Ocean during INDOEX pre-campaign cruises of 1996, 1997, and 1998 on Sagar Kanya, Curr. Sci. 76(7) 944-946.

Jayakumar D A, Naqvi S W A, Narvekar P V and Geroge M D 2001 Methane in coastal and offshore waters of the Arabian Sea, Marine Chemistry 74 1-13.

Johnson J E, Gammon R H, Larson J, Bates T S, Oltmans S J and Farmer C 1990 Ozone in the marine 
boundary layer over the Pacific and Indian Ocean: Latitudinal gradients and diurnal cycles; J. Geophys. Res. 95(D8) 11,847-11,856.

Kita K et al 2003 Photochemical production of ozone in the upper troposphere in association with cumulus convection over Indonesia; J. Geophys. Res. 108(D3) 8400, doi:10.1029/2001JD000844.

Krishnamurthy K, Satheesh S K and Krishnamurthy B V 1998 Characteristics of special optical depths and size distribution of aerosols over tropical oceanic region; J. Atmospheric and Solar Terrestrial Phys. 60 981-992.

Kumar M D, Naqvi S W A, George M D and Jayakumar D A 1996 A sink for atmospheric carbon dioxide in the northern Bay of Bengal; J. Geophys. Res. 101 $18,121-18,125$.

Kunhikrishnan T, Lawrence M G, von Kuhlmann R, Richter A, Ladstatter-Weibenmayer A and Barrows J P 2004 Semiannual $\mathrm{NO}_{2}$ plumes during the monsoon transition periods over the central Indian Ocean; Geophys. Res. Lett. 31 L08110, doi:10.1029/2003GL019269.

Lake B J, Noor S M, Freitag H P and McPhaden M J 2003 Calibration procedures and instrumental accuracy estimates of ATLAS air temperature and relative humidity measurements; NOAA Tech Memo. OAR PMEL-123, NOAA/Pacific Marine Environmental Laboratory, Seattle, WA, $23 \mathrm{pp}$.

Lal S, Patra P K, Venkataramani S and Sarin M M 1996 Distribution of nitrous oxide and methane in the Arabian Sea; Curr. Sci. 71 894-899.

Lal S, Naja M and Jayaraman A 1998 Ozone in the marine boundary layer over the tropical Indian Ocean; J. Geophys. Res. 103(D15) 18,907-18,917.

Lal S and Patra P K 1998 Variabilities in the fluxes and annual emissions of nitrous oxide from the Arabian Sea; Global Biogeochem. Cycles 12 321-327.

Lal S, Chand D, Sahu L K, Venkataramani S, Brasseur G and Schultz M G 2006 High levels of ozone and related gases over the Bay of Bengal during winter and early spring of 2001; Atmos. Environ. 40 1633-1644.

Lelieveld et al 2001 The Indian Ocean Experiment: Widespread air pollution from south and southeast Asia; Science 291 1031-1036.

Mukhopadhyay S K, Biswas H, De T K, Sen B K, Sen S and Jana T K 2002 Impact of Sunderban mangrove biosphere on the carbon dioxide and methane mixing ratios at the NE coast of Bay of Bengal; Atmos. Environ. 36(2) 629-638.

Muhle J, Zahn A, Brenninkmeijer C A M, Gros V and Crutzen P J 2002 Air mass classification during the INDOEX R/V Ronald Brown cruise using measurements of nonmethane hydrocarbons, $\mathrm{CH}_{4}, \mathrm{CO}_{2}, \mathrm{CO},{ }^{14} \mathrm{CO}$, and ${ }^{18} \mathrm{C}(\mathrm{CO})$, J. Geophys. Res. 107(D19) 8021, doi: 10.1029/2001JD000730.

Naja M, Shyam Lal, Venkataramani S, Modh K S and Duli Chand 1999 Variabilities in $\mathrm{O}_{3}, \mathrm{NO}, \mathrm{CO}$, and $\mathrm{CH}_{4}$ over the Indian Ocean during winter; Curr. Sci. 7(7) 931-937.

Naqvi S W A, Yoshinari T, Jayakumar D A, Altabet M A, Narvekar P V, Devol A H et al 1998 Budgetary and biogeochemical implications of $\mathrm{N}_{2} \mathrm{O}$ isotope signatures in the Arabian Sea; Nature 394 462-464.

Naqvi S W A, Jayakumar D A, Narvekar P V, Naik H, Sarma V V S S, D'Souza W et al 2000 Increased marine production of $\mathrm{N}_{2} \mathrm{O}$ due to intensifying anoxia on the Indian continental shelf; Nature 408 346-349.

Naqvi S W A, Bange $\mathrm{H}$ W, Gibb $\mathrm{S}$ W, Goyet C, Hatton A D and Upstill-Goddard R C 2005 Biochemical ocean-atmosphere transfers in the Arabian Sea; Progr. Oceanogr. 65 116-144.

Parrish D D, Trainer M, Holloway J S, Yee J E, Warshawsky M S and Fehsenfeld F C 1998 Relationships between ozone and carbon monoxide at surface sites in the North Atlantic Ocean, J. Geophys. Res. 103(D11) 13,357-13,376.

Patra P K, Lal S, Venkataramani S, Gauns M and Sarma V V S S 1998 Seasonal variability in distribution and fluxes of methane in the Arabian Sea; J. Geophys. Res. 103 1167-1176.

Patra P K, Lal S, Venkataramani S, de Sousa S N, Sarma V V S S and Sardesai S 1999 Seasonal and spatial variability in $\mathrm{N}_{2} \mathrm{O}$ distribution in the Arabian Sea; Deep-Sea Res. I 46 529-543.

Ramachandran S 2005 PM2.5 mass concentration in comparison with aerosol optical depths over the Arabian Sea and Indian Ocean during winter monsoon; Atmos. Environ. 39(10) 1879-1890.

Ramanathan et al 2001 Indian Ocean Experiment: An Integrated analysis of the climate forcing and effects of the great Indo-Asian haze; J. Geophys. Res. 106(D22) 28,371-28,398.

Rhoads K P, Dickerson R R, Kelley P, Carsey T, Farmer M, Savie D and Prospero J 1997 The comparison of the troposphere over the Indian Ocean during the monsoonal season; J. Geophys. Res. 102(15) 18,981-18,995.

Sanjeeva Rao P 2005 Arabian Sea monsoon Experiment, An overview, Mausam 56(1) 1-6.

Sarma V V S S, Dileep Kumar M, Gauns M and Madhupratap M 2000 Seasonal controls on surface $\mathrm{pCO}_{2}$ in the central and eastern Arabian Sea; Proc. Indian Acad. Sci. (Earth Planet. Sci.) 109(4) 471-479.

Stehr J W, Ball W P, Dickerson R R, Doddridge B G, Piety C A and Johnson J E 2002 Latitudinal gradients in $\mathrm{O}_{3}$ and $\mathrm{CO}$ during INDOEX 1999; J. Geophys. Res. 107(d19) 8015, doi: 10.1029/2001JD000446.

Thompson A M 1992 The oxidizing capacity of the Earth's atmosphere: Probable past and future changes; Science 256 1157-1165.

Wanye R P 1991 Chemistry of Atmospheric: An Introduction to the Chemistry of the Atmospheres of Earth, the Planet, and their Satellites (Oxford University Press) $581 \mathrm{pp}$. 